\title{
The Effect of Immersed Heat Cured Acrylic Resin Denture Base in Clorhexidin and Extract of Roselle Flower towards Color Stability
}

\author{
Mohammad Zulkarnain \\ Department of Prosthodontics \\ Faculty of Dentistry, Universitas Sumatera Utara \\ Medan, Indonesia
}

\author{
Putri Angelyna \\ Student \\ Faculty of Dentistry, Universitas Sumatera Utara \\ Medan, Indonesia
}

\begin{abstract}
The most commonly used denture base material is heat cured acrylic resin. This material possesses chemical properties, such as color stability. Discoloration of the denture base can be caused by the use of disinfectant solution on daily basis. This is caused by the characteristic of acrylic resin which absorbs water over long contact times with solutions. The most common disinfectant solution used is chlorhexidine gluconate $0.2 \%$. But, nowadays there are a lot of natural substances that could be used as alternatives to chemical substances such as roselle flower. This is a laboratory experimental study using cylinder shape sample with diameter of $50 \pm 0.1 \mathrm{~mm}$ and $0.5 \pm 0.1 \mathrm{~mm}$. The total of 60 samples is classified to 12 groups. The result shows significant result in discoloration with the usage of Chlorhexidine gluconate $0,2 \%$ in 1 year (92 hours), 2 years (183 hours), and 3 years (274 hours) with $p=0.01(p<0.05), p=0.001(p<0.05), p=0.001(p<0.05)$, and the roselle flower group in 3 years (183 hours) with $p=0.021 \quad(p<0.05)$. This study shows significant effect between time of usage to discoloration in acrylic resin groups that are soaked with the extract of roselle flower in 1 year (61 hours), 2 years (122 hours), and 3 years (183 hours) of contact with $p=0.025$. Roselle's extract of $40 \%$ can be used as natural disinfectant solution of heat cured acrylic resin.
\end{abstract}

Keywords-denture base, heat cured acrylic resin, disinfectant, color stability

\section{INTRODUCTION}

The most commonly used denture base material is heat cured acrylic resin. The heat cured acrylic resin meets the requirement as a denture base because this material is not toxic, does not irritate tissue, is aesthetically pleasing, relatively cheap and can be prepared [1,2]. One of the heat cured acrylic resin's chemical properties is color stability. Color stability is the ability of a material to retain its color even though there is little discoloration from its original color [3]. The lesser color changes occur in a material, the better its color stability. The occurrence of color change is caused by two factors which is intrinsic and extrinsic. The intrinsic factor is the chemical change in the material itself that is an imperfect polymerization process. Extrinsic factors are stains which arise from the absorption of dyes from exogenous sources such as tea, coffee, soft drinks, nicotine and mouthwash [4].
The use of denture causes the base to contact with microorganisms that require regular cleaning of denture base. When the denture is not cleaned properly, it will cause unpleasant odor, accumulation of calculus and denture stomatitis [5]. The most common way used to clean denture is by immersing denture into chemical liquid that contains cleaning agent, such as $0.2 \%$ chlorhexidine gluconate. Chlorhexidine gluconate is an effective and broad-spectrum bis-bisquanite dentative, works fast and has low toxicity. Chlorhexidine contains chlorine which can cause bleaching on acrylic resins. The longer heat cured acrylic resin immersed in Chlorhexidine, the more its pigment fade. According to the research of David and Munadzirah (2005), there was a significant change in the base of heat cured acrylic resin after immersion in Chlorhexidine gluconate for 105 minutes [6].

Nowadays, there is natural cleaning agent that could be used such as Roselle flower. Rosella flower is widely used by people as food such as beverage (rosella tea) and medicine for the body [7]. In rosella flower contains compound that include polyphenols of flavonoid groups such as anthocyanin, tannin and saponin [8]. These flavonoid compounds can inhibit the growth of candida albicans because of its ability to form complex compounds with proteins and ate antiviral. These anthocyanin pigments provide a reddish color to the rosella flowers perans. Tannin is and acidic polyphenol compound that can cause the disruption of acrylic resin polymer chain bonds and increase porosity which can read the color change $[9,10]$. Saponins are glycosides and are effective against of candida albicans that work by intervening with the integrity of candida albicans cell [11]. According to the study Aditiana et al (2011), there were no significant discoloration on the denture base of heat cured acrylic resin after immersing in rosella water for 37 and 49 hour [12].

The purpose of this study is to determine the effect of immersion heat cured acrylic resin denture base in $0.2 \%$ chlorhexidine gluconate during 1 year (92 hours), 2 years (183 hours), 3 year (274 hours) and $40 \%$ rosella flower extract during 1 year (61 hours), 2 years (122 hours), 3 years (183 hours) usage towards color stability. 


\section{MATERIALS AND METHODS}

4 grams of concentrated rosella flowers extract was dissolved in aquadest up to $10 \mathrm{ml}$ to obtain $40 \%$ rosella flower extract. The sample was prepared following the ADA specification no. 12 by using heat cured acrylic resin (brand qc 20) in the form of a cylinder with a diameter of $50 \pm 0.1 \mathrm{~mm}$ and $0.5 \pm 0.1 \mathrm{~mm}$. The sample preparation is as follows, the cuvette containing mold form the parent model which has been placed on the gypsum, the mold is then filled with heat cured acrylic resin dough which is also known as the dough stage and then the cuvette is closed and placed in the waterbath at temperature $70 \%$ for 90 minutes and $100 \%$ for 30 minutes. Once sample cooled down, the sample is then removed from the cuvette and trimmed with fraser bur and is smoothed using a waterproof sandpaper with fraser bur and is smoothed using waterproof sandpaper no. 600 which is connected to rotary grinder under running water. All samples were immersed in aquadest for 50 hours to achieve maximum saturation levels and reduce residual monomers. The total number of samples was 60 fruits which was divided into 12 groups with group A chlorhexidine gluconate $0.2 \% 2$ years (92 hours), group B chlorhexidine gluconate $0.2 \% 2$ years (183 hours), group C chlorhexidine gluconate $0.2 \% 3$ years (274 hours), group D control extract of rosella flowers $40 \% 1$ year (61 hours), group E control extract of rosella flowers $40 \% 2$ years (122 hours). Group F control extract of rosella flowers $40 \% 3$ years (183 hours). After the immersion, all samples were removed and were allowed to dry and then tested the color changes using UV-VIS spectrophotometer. The analysis of data was performed by univariat test, 1-independent test and one-way ANOVA test.

\section{RESULTS}

The result shows the average value of color stability analyzed by using univariat test with the average value and standard deviation of group $\mathrm{A}$ is $0.034 \pm 0.011$. The mean and standard deviation of group $\mathrm{B}$ is $0.027 \pm 0.011$. The mean and standard deviation of group $\mathrm{C}$ is $0.021 \pm 0.006$. The mean and standard deviation of group $\mathrm{D}$ is $0.075 \pm 0.011$. The mean and standard deviation of group $\mathrm{E}$ is $0.092 \pm$ 0.021 . The mean and standard deviation of group $F$ is $0.122 \pm 0.033$. The mean and standard deviation of group $\mathrm{D}$ is $0.073 \pm 0,016$. The mean and standard deviation of group $\mathrm{A}$ is $0.072 \pm 0,011$. The mean and standard deviation of group $\mathrm{E}$ is $0.071 \pm 0,011$. The mean and standard deviation of group B is $0.067 \pm$ 0,006 . The mean and standard deviation of group $\mathrm{F}$ is $0.067 \pm 0.006$. The mean and standard deviation of group $\mathrm{C}$ is $0.062 \pm 0.011$.

Based on t-independent test shows a significant influence in group A with values of $p=0.001(\mathrm{p}<0.05)$, group $B$ with value of $p=0.001(p<0.05)$, group $C$ with value of $p=0.001(p<0.05)$, and group $F$ with value of $\mathrm{p}=0.021(\mathrm{p}<0.05)($ Table I).
TABLE I. THE EFFECT OF IMMERSION HEAT CURED ACRYLIC RESIN DENTURE BASE IN $0,2 \%$ CHLORHEXIDINE GLUCONATE DURING 1 YEAR (192 HOURS), 2 YEARS (183 HOURS), 3 YEARS (274 HOURS) AND EXTRACT OF ROSELLA FLOWER 40\% FOR 1 YEAR (61 HOURS), 2 YEARS (122 HOURS), 3 YEARS (183 HOURS) OF USAGE TOWARDS COLOR STABILITY

\begin{tabular}{|c|c|c|}
\hline Group & $\mathbf{n}$ & $\mathbf{p}$ \\
\hline $\mathrm{A}$ & 5 & \multirow{2}{*}{$0.001 *$} \\
\hline $\mathrm{A}^{\prime}$ & 5 & \\
\hline B & 5 & \multirow{2}{*}{$0.001 *$} \\
\hline $\mathrm{B}^{\prime}$ & 5 & \\
\hline $\mathrm{C}$ & 5 & \multirow{2}{*}{$0.001 *$} \\
\hline $\mathrm{C}^{\prime}$ & 5 & \\
\hline $\mathrm{D}$ & 5 & \multirow{2}{*}{0.873} \\
\hline $\mathrm{D}^{\prime}$ & 5 & \\
\hline$E$ & 5 & \multirow{2}{*}{0.086} \\
\hline$E^{\prime}$ & 5 & \\
\hline $\mathrm{F}$ & 5 & \multirow{2}{*}{$0.021 *$} \\
\hline $\mathrm{F}^{\prime}$ & 5 & \\
\hline
\end{tabular}

Based on ANOVA test shows a significant valve of $\mathrm{p}=0.127 \quad(\mathrm{p}>0.05)$ in chlorhexidine gluconate. This value indicate no effect of long term immersion of heat cured acrylic resin denture base in chlorhexidine gluconate $0.2 \%$ during 1 year, 2 years and 3 years of usage towards color stability (Table II) and $\mathrm{p}=0.025$ $(p<0.05)$ in extract of rosella flower. This value indicate effect of long term immersion of heat cured acrylic resin denture base in extract of rosella flower 40 during 1 year, 2 years and 3 years of usage towards color stability (Table III).

TABLE II. THE EFFECT OF LONG TERM IMMERSION OF HEAT CURED ACRYLIC RESIN DENTURE BASE IN CHLORHEXIDINE GLUCONATE 0,2\% DURING 1 YEAR (92 HOURS), 2 YEARS (183 HOURS) AND 3 YEARS (274 HOURS) OF USAGE TOWARD COLOR STABILITY

\begin{tabular}{|c|c|c|}
\hline Group & $\overline{\overline{\mathbf{x}}} \pm$ SD & $\mathbf{p}$ \\
\hline A & $0.034 \pm 0,011$ & \multirow{2}{*}{0.127} \\
\hline B & $0.027 \pm 0.011$ & \\
\hline C & $0.021 \pm 0.007$ & \\
\hline
\end{tabular}

TABLE III. THE THE EFFECT OF LONG TERM IMMERSION OF HEAT CURED ACRYLIC RESIN DENTURE BASE IN EXTRACT OF ROSELLA FLOWER 40\% DURING 1 YEAR (61 HOURS), 2 YEARS (122 HOURS) AND 3 YEARS (183 HOURS) OF USAGE TOWARD COLOR STABILITY

\begin{tabular}{|c|c|c|}
\hline Group & $\overline{\mathrm{x}} \pm$ SD & \multirow{2}{*}{$\mathbf{P}$} \\
\hline $\mathrm{D}$ & $0.075 \pm 0.011$ & \multirow{2}{*}{$0.025^{*}$} \\
\hline $\mathrm{E}$ & $0.092 \pm 0.021$ & \\
\hline $\mathrm{F}$ & $0.122 \pm 0.0338$ & \\
\hline
\end{tabular}

\section{DISCUSSION}

The denture base of heat cured acrylic resin's color may be changed after being used for a certain period of time. This occurs because acrylic resin has the properties of absorbing water slowly according to the law of diffusion [12]. The result shows the average absorbing value in chlorhexidine group is lower than the control group. Group C (chlorhexidine 3 years) (274 hours) has the most faded color compared to any other group. The independent t-test result shows a significant 
effect in group which was immersed in chlorhexidine 1 years (92 hours), 2 years (183 hours) and 3 years (274 hours) of usage compared to the control group. This is due to the interaction of cations and anions of chlorine compounds contained in chlorhexidine with heat cured acrylic resin till the dye in the denture base turn white, the longer the immersion in chlorhexidine can result in the denture-colored base pigment of acrylic resin bleaching resulting in greater color change [6]. Color pigment in heat cured acrylic resin will react with chlorine ions due to prolonged contact with chlorhexidine fluid and chlorine ion absorption into the porosity of heat cured acrylic resin which dissolves heat cured acrylic resin pigment [4].

The mean of absorbance value in the sample groups immersed in extract of rosella flower was $40 \%$ greater than those in the control groups. Color group F (rosella 3 years) (183 hours) is the darkest compared to the other groups. T-independent test result show a significant effect on group $\mathrm{F}$ compared to the control group. This is due to prolonged exposure till the natural dye in rosella flower; the anthocyanin pigment can be diffused into the acrylic resin [7]. The stability of anthocyanin pigment is influenced by $\mathrm{pH}$ and temperature. These anthocyanin pigments are most stable in acidic conditions or in low $\mathrm{pH}$ conditions $(\mathrm{pH}$ 1-3). The degradation rate of these anthocyanin pigments also increases as the temperature increases. The anthocyanin pigment is stable $50^{\circ} \mathrm{C}$ [14]. In addition, immersion of acrylic resins in rosella flower extracts containing acidic tannins over long periods of time can disrupt the polymer chains in order to increase porosity and cause discoloration due to increase in tannin absorption [10]. According to Anusavice, the color changes that occur in heat cured acrylic resin may vary, this is due to several factors, including sample size, sample microporosity and duration of contact between materials. The larger the sample size the greater the physical change in the material occurs [7]. The microporosity determines the attachment of the porous regions color particles. The greater the porosity hence accumulation from the dye that has been absorbed through diffusion will also increase. The longer the contact between the acrylic resin and color substance will affect the color changes, this is because the longer the resin material is immersed the greater the change occurs [7].

Based on the result of the above experiments the immersion of heat cured acrylic resin in chlorhexidine gluconate $0.2 \%$ was discolored after denture wear for 1 year (92 hours) and immersion of heat cured acrylic resin in extract of rosella flower $40 \%$ was discolored after denture wear for 2 year (122 hours). From the result above can be concluded that roselle's extract of $40 \%$ can be used as natural disinfectant solution of heat cured acrylic resin.

\section{REFERENCES}

[1] Anusavice, J. Kenneth, Phillips buku ajar ilmu bahan kedokteran gigi, Trans: J.A. Budiman, S. Puwoko, L. Juwono. Ed. 10, Jakarta: EGC, 2003, pp. 192-225.

[2] E. Wahyuningtyas, "Pengaruh ekstrak graptophyllum pictum terhadap pertumbuhan Candida albicans pada plat gigi tiruan resin akrilik," IJD., vol. 15(3), pp. 187-1888, 2008.

[3] N. Padiyar, P. Kaurani, "Color stability: An important physical property of esthetic restorative materials," IJCDS., vol. 1(1), pp. 81-84, 2010

[4] Y. Kangsudarmanto, dkk, "Perbandingan perubahan warna Heat Cured Acrylic basis gigi tiruan yang direndam dalam klorheksidin dan effervescent (alkaline peroxide)," Dentino, vol. 2(2), pp. 205-9, 2014.

[5] N. Pristianingrum, Soebagio, E. Munadziroh, "Uji stabilitas mikrobiologis pembersih gigi tiruan dengan bahan minyak atsiri kulit batang kayu manis (Cinnamomumburmannii)," Jurnal PDGI., vol. 62(3), pp. 89-94, 2013.

[6] David, E. Munadziroh, "Perubahan warna lempeng resin akrilik yang direndam dalam larutan desinfektan sodium hipoklorit dan klorheksidin,” Majalah Kedokteran Gigi, vol. 38(1), pp. 36-40, 2005.

[7] Irfany, dkk., "Stabilitas warna basis akrilik gigi tiruan lepasan setelah pembersihan dengan ekstrak infusa bunga rosella," Dentofasial, vol. 13(1), pp. 38-42, 2014.

[8] A. Ratnasari, W. Widajati, N. Hendrijantini, "Efek seduhan bunga rosella dalam menghambat pertumbuhan Candida albicans pada resin akrilik," Journal of Prosthodontics, vol. 4(1), pp. 22-26, 2013.

[9] T. Abdullah, H. Eri, "Ekstrak tongkol jagung (Zeamays L) sebagai bahan desinfektan gigi tiruan terhadap Candida albicans," Makassar Dent. J., vol. 5(3), pp. 82-86, 2016.

[10] I. Baga I, S. Handajani, A.R. Putri, "Efek lama perendaman resin akrilik heat cured dalam minuman teh hijau (Camella Sinensis) terhadap perubahan warna," Fakultas Kedokteran Gigi Brawijaya.

[11] Rosidah, dkk., "Daya antibakteri ekstrak daun kendali (Hippobromalongiflora L G. Don) terhadap pertumbuhan Streptococcusmutans," Jurnal Pustaka Kesehatan, 2014.

[12] R. Aditiana, E. Pudjirochani, M. Josef, "Pengaruh perendaman dalam minuman rosella terhadap warna resin akrilik heatcured," Journal of Prosthodontics, vol. 2(1), pp. 45-50, 2011.

[13] Z.Y. Duymus, N. Yanikoglu, M. Arik, "Evaluation of color changed of acrylic resin materials in the different solutions," Asian J. Chem., vol. 22(9), pp. 6669-6676, 2010.

[14] W. Ingrath, W.A. Nugroho, R. Yulianingsih, "Ekstraksi pigmen antosianin dari kulit buah naga merah (Hylocereuscostaricensis) sebagai pewarna alami makanan dengan menggunakan microwave (kajian waktu pemanasan dengan microwave dan penambahan rasio pelarut aquades dan asam sitrat," Jurnal Bioproses Komoditas Tropis, vol. 3(3), pp. 1-8, 2015. 